\title{
EFEKTIVITAS DIKLAT BERJENJANG TINGKAT DASAR TERHADAP PENINGKATAN KOMPETENSI SOSIAL PENDIDIK PAUD (STUDI DESKRIPTIF PADA PENDIDIK PAUD DI KOTA CIMAHI)
}

\author{
${ }^{1)}$ Agus Sumitra, ${ }^{2)}$ Lenny Nuraeni, ${ }^{3)}$ Heni Nafiqoh \\ ${ }^{1)}$ agussumitra@ikipsiliwangi.ac.id \\ ${ }^{1,2,3,}$ Program Studi PGPAUD, Fakultas Ilmu Pendidikan, IKIP Siliwangi
}

\begin{abstract}
ABSTRAK
Penelitian ini akan membahas tentang: "Efektivitas Diklat Berjenjang Tingkat Dasar Terhadap Peningkatan Kompetensi Profesional dan Sosial Pendidik PAUD. Tujuan Penelitian ini adalah sebagai berikut: 1) Menganalisis kompetensi profesional Pendidik PAUD setelah mengikuti Pelatihan Tingkat Dasar di Kota Cimahi, 2) Menganalisis Kompetensi Sosial Pendidik PAUD setelah mengikuti Diklat berjenjang tingkat dasar di Kota Cimahi, 3) Menganalisis efektivitas Diklat Berjenjang Tingkat Dasar terhadap peningkatan kompetensi profesional dan sosial Pendidik PAUD di Kota Cimahi.

Adapun kegunaan penelitian ini adalah sebagai berikut:

1. Kegunaan teoritik, yang kemudian hasil penelitian ini diharapkan dapat memperkaya teori-teori pendidikan serta dapat menjadi salah satu referensi untuk mengembangkan program PAUD khususnya tentang Diklat Berjenjang Tingkat Dasar bagi Pendidik Pendidikan Anak Usia Dini.

2. Kegunaan praktis, dimana hasil penelitian ini diharapkan dapat dijadikan bahan masukan serta bahan pertimbangan bagi penyelenggara Diklat Berjenjang Tingkat Dasar di Wilayah Kota Cimahi baik yang dilaksanakan oleh pihak pemerintah maupun pihak swasta.

3. Sebagai bahan kajian dan kontribusi bagi Prodi Pendidikan Anak Usia Dini yang diharapkan dapat bermanfaat dalam rangka pengembangan disiplin pengetahuan.

Untuk menguji hipotesis digunakan metode deskriptif analitik dengan teknik pengumpulan data wawancara, angket, observasi, studi literatur, dan studi dokumentasi. Populasi seluruh Pendidik PAUD di Kota Cimahi dengan Sampel sebanyak 108 orang dengan cara proportional random sampling.

Hasil analisis data berdasarkan perhitungan menunjukan bahwa persamaan regresi yang diperoleh adalah $\mathrm{Y}=\mathrm{Y}=$ $46,106+0.665 \mathrm{X}$ koefisien regresi yang menunjukan harga yang positif. Pada perhitungan koefisien determinasi menunjukan bahwa efektivitas diklat berjenjang tingkat dasar dalam meningkatkan kompetensi profesional pendidik PAUD di Kota Cimahi adalah 23,9 \% sedangkan sisanya 76,1\% dipengarui oleh faktor lain. Hasil analisis data penelitian mengenai efektivitas diklat berjenjang tingkat dasar terhadap peningkatan kompetensi sosial pendidik PAUD di Kota Cimahi, berdasarkan perhitungan menunjukan bahwa persamaan regresi yang diperoleh adalah $\mathrm{Y}=40,846+$ $0.886 \mathrm{X}$ koefisien regresi yang diperoleh menunjukan harga yang positif. Pada perhitungan koefisien determinasi menunjukan bahwa efektivitas diklat berjenjang tingkat dasar dalam meningkatkan kompetensi sosial pendidik PAUD di Kota Cimahi adalah 31,1\% sedangkan sisanya 68,9\% dipengarui oleh faktor lain.
\end{abstract}

Kata Kunci: Diklat berjenjang tingkat Dasar, Kompetensi pedagogik, Pendidik PAUD

\begin{abstract}
This research will discuss about: "The Effectiveness of Basic Leveled Training on the Elevation of Professional and Social Competence of early childhood education teachers. The purpose of this study are as follows: 1) Analyze the competence of PAUD Educator Professional after attending Basic Training in Cimahi City, 2) Analyzing Early Childhood Education Competence after attending the Basic Leveled Training in Cimahi City, 3) Analyzing the effectiveness of Basic Leveled Training on improvement professional and social competence of early childhood education teachers in Cimahi City. The usefulness of this research is as follows: 1. Theoretical usefulness, which then the results of this study is expected to enrich the theories of education and can be a reference to develop the early childhood education program on Basic Level Training for Early Childhood Education Educators. 2. Practical usefulness, where the results of this study is expected to be used as input materials and consideration materials for the organizers of Basic Leveled Training in Cimahi City Region either implemented by the government or private parties. 3. As study materials and contributions for Early Childhood Education Prodi which is expected to be useful in the framework of development of knowledge discipline. To test the hypothesis used analytical descriptive method with data collection techniques interviews, questionnaires, observations, literature studies, and documentation studies. Population of all early childhood education teachers in Kota Cimahi with a sample of 108 people by proportional random sampling. The result of data analysis based on the calculation shows that the regression equation obtained is $\mathrm{Y}=\mathrm{Y}=46,106+$ $0.665 \mathrm{X}$ regression coefficient showing the positive price. In the calculation of the coefficient of determination shows
\end{abstract}


that the effectiveness of the basic level of training in improving the competence of professional early childhood education teachers in Cimahi City is $23.9 \%$ while the remaining $76.1 \%$ is influenced by other factors. The result of analysis of research data on the effectiveness of the basic level of education and training on the improvement of social competence of early childhood education teachers in Kota Cimahi, based on the calculation shows that the regression equation obtained is $\mathrm{Y}=40.846+0.886 \mathrm{X}$ the obtained regression coefficient shows the positive price. In the calculation of the coefficient of determination shows that the effectiveness of the basic level of training in improving the social competence of early childhood educator in Cimahi City is $31.1 \%$ while the remaining $68.9 \%$ is influenced by other factors.

Key Words: Basic level training, Pedagogic competency, early childhood Education teachers

\section{A. PENDAHULUAN}

Berbagai permasalahan yang timbul dalam suatu pendidikan salah satunya muncul dari mutu dan kualitas pendidikan itu sendiri. Baik itu pendidik, sistem ataupun peserta didiknya. Semua itu merupakan suatu sistem fungsional yang akan terus berjalan beriringan dan tidak akan bisa berjalan apabila salah satu dari ketiga itu tidak ada. Mutu pendidikan yang baik dapat mendorong terciptanya masyarakat yang berkualitas, kreatif dan produktif. Salah satu ciri dari mutu pendidikan yang baik adalah terciptanya proses pembelajaran yang baik pula (mulai dari perencanaan, pelaksanaan, maupun evaluasi). Sebagai dampaknya guru yang merupakan peran sentral dalam proses pembelajaran sudah sewajarnya dituntut untuk lebih profesional dalam menjalankan fungsinya. Selain hal tersebut, perubahan dan perkembangan masyarakat yang semakin maju juga menuntut profesi guru menyesuaikan diri dengan perubahan dan kebutuhan masyarakat.

Guru adalah pendidik profesional dengan tugas utama mendidik, mengajar, membimbing, mengarahkan, melatih, menilai, mengevaluasi peserta didik pada pendidikan anak usia dini jalur formal, non formal dan informal. Guru adalah salah satu di antara faktor pendidikan yang memiliki peranan yang paling strategis, sebab gurulah sebetulnya yang paling menentukan di dalam terjadinya proses belajar mengajar.

Guru memiliki peran yang sangat penting dalam menentukan kuantitas dan kualitas pengajaran yang pada akhirnya berperan dalam meningkatkan mutu pendidikan nasional. Guru berperan sebagai pengelola proses belajar mengajar, bertindak selaku fasilitator yang berusaha menciptakan proses belajar mengajar yang efektif, mengembangkan bahan pelajaran dengan baik dan meningkatkan kemampuan peserta didik untuk menyimak pelajaran dan menguasai tujuan-tujuan pendidikan yang harus mereka capai.

Hal ini menuntut perubahan-perubahan dalam pengorganisasian kelas, pengelolaan kelas, penggunaan metoda mengajar, strategi belajar mengajar, maupun sikap dan karakteristik guru dalam mengelola proses belajar mengajar. Untuk memenuhi hal tersebut di atas, guru harus mampu mengelola proses belajar mengajar yang memberikan rangsangan kepada peserta didik sehingga ia mau belajar karena memang peserta didiklah subjek utama dalam belajar. Guru yang mampu melaksanakan perannya sesuai dengan yang disebutkan di atas disebut sebagai seorang guru yang berkompetensi. Sebagai standar kompetensi yang perlu dimiliki oleh guru dalam melaksanakan profesinya, pemerintah mengeluarkan Permendiknas Nomor 16 Tahun 2007 tentang Kualifikasi Akademik dan Kompetensi Guru. Standar kompetensi guru ini dikembangkan secara utuh dari empat kompetensi utama, yaitu kompetensi pedagogik, kepribadian, sosial, dan profesional.

Pengembangan dan peningkatan kualitas kompetensi guru selama ini diserahkan kepada guru itu sendiri. Jika guru itu mau mengembangkan dirinya sendiri, maka guru itu akan berkualitas, karena ia senantiasa mencari peluang untuk meningkatkan kualitasnya sendiri. Idealnya pemerintah, asosiasi pendidikan dan guru serta satuan pendidikan memfasilitasi guru untuk mengembangkan kemampuan bersifat kognitif berupa pengertian dan pengetahuan, afektif berupa sikap dan nilai, maupun performansi berupa perbuatan-perbuatan yang mencerminkan pemahaman keterampilan dan sikap. Dukungan yang demikian itu penting, karena dengan cara itu akan meningkatkan kemampuan pedagogik bagi guru. Karena pentingnya hal tersebut, maka pembahasan dalam laporan penelitian ini lebih difokuskan pada kompetensi profesional dan sosial guru. 
Guru sebagai pendidik professional mempunyai citra yang baik di masyarakat apabila dapat menunjukan kepada masyarakat bahwa ia layak menjadi panutan atau teladan masyarakat sekelilingnya. Masyarakat terutama akan melihat bagaimana sikap dan perbuatan guru itu seharihari, apakah memang ada yang patut diteladani atau tidak. Bagaimana guru meningkatkan pelayanannya, meningkatkan pengetahuannya, memberi arahan dan dorongan pada anak didiknya, dan bagaimana cara guru berpakaian dan berbicara serta cara begaul baik dengan siswa, teman-temannya serta anggota masyarakat, sering menjadi perhatian masyarakat luas.

Walaupun segala perilaku guru selalu di perhatikan masyarakat, tetapi yang akan dibicarakan dalam bagian ini adalah khusus prilaku guru yang berhubungan dengan profesinya. Hal ini berhubungan dengan bagaimana pola tingkah laku guru dalam memahami, menghayati, serta mengamalkan sikap kemampuan dan sikap profesionalnya. Pola tingkah laku guru yang berhubungan dengan itu akan dibicarakan sesuai dengan sasarannya, yakni sikap profesional keguruan terhadap: Peraturan perundang-undangan, Organisasi profesi, Teman sejawat, Anak didik, Tempat kerja, Pemimpin, Pekerjaan

Kompetensi sosial terkait dengan kemampuan guru sebagai makhluk sosial dalam berinteraksi dengan orang lain. Sebagai makhluk sosial guru berperilaku santun, mampu berkomunikasi dan berinteraksi dengan lingkungan secara efektif dan menarik mempunyai rasa empati terhadap orang lain. Kemampuan guru berkomunikasi dan berinteraksi secara efektif dan menarik dengan peserta didik, sesama pendidik dan tenaga kependidikan, orangtua dan wali peserta didik, masyarakat sekitar sekolah dan sekitar di mana pendidik itu tinggal, dan dengan pihak-pihak berkepentingan dengan sekolah. Kondisi objektif ini menggambarkan bahwa kemampuan sosial guru tampak ketika bergaul dan melakukan interaksi sebagai profesi maupun sebagai masyarakat, dan kemampuan mengimplementasikan dalam kehidupan seharihari.

Dalam rangka meningkatkan kompetensi profesional dan kompetensi sosial tersebut, salah satunya dilakukan kegiatan pelatihan. Pelatihan guru seharusnya dilakukan sebagai bahan bagi guru untuk menyusun laporan kepada orang tua anak dan memantau perkembangan anak sehingga bisa digunakan untuk menyempurnakan perencanaan program pembelajaran selanjutnya, serta juga melakukan langkah-langkah yang tepat jika ternyata dalam pembelajaran terdapat penemuan perkembangan anak yang tidak sesuai dengan pola perkembangan serta pertumbuhan pada umumnya. Tentu saja hal ini disebabkan karena kurangnya kesadaran guru akan pentingnya pelatihan yang dilakukan oleh guru bagi peningkatan prestasi belajar siswa. Semakin sering dilakukan pelatihan oleh guru maka semakin baik pula prestasi yang akan diraih oleh siswa. Oleh karena itu, kondisi ini memberi inspirasi khusus bagi penulis untuk melakukan penelitian tentang: "Efektivitas Diklat Berjenjang Tingkat Dasar terhadap Peningkatan Kompetensi Profesional dan Sosial Pendidik PAUD di Kota Cimahi”.

Berdasarkan rumusan masalah dan pertanyaan penelitian diatas, maka dirumuskan beberapa tujuan Penelitian untuk memperoleh temuan sebagai berikut :

1. Menganalisis kompetensi profesional pendidik PAUD setelah mengikuti Diklat Berjenjang Tingkat Dasar di Kota Cimahi.

2. Menganalisis kompetensi sosial pendidik PAUD setelah mengikuti Diklat Berjenjang Tingkat Dasar di Kota Cimahi.

3. Menganalisis Efektivitas Diklat Berjenjang Tingkat Dasar terhadap peningkatan kompetensi profesional dan sosial Pendidik Anak Usia Dini di Kota Cimahi

Adapun Manfaat yang dapat diambil dari kegiatan penelitian ini adalah dapat memberikan kontribusi bagi beberapa pihak yang terkait. Adapun kegunaan penelitian ini adalah sebagai berikut:

1. Kegunaan teoritik, yang kemudian hasil penelitian ini diharapkan dapat memperkaya teori-teori pendidikan serta dapat menjadi salah satu referensi untuk mengembangkan program PAUD khususnya tentang Diklat Berjenjang Tingkat Dasar bagi Pendidik Pendidikan Anak Usia Dini.

2. Kegunaan praktis, dimana hasil penelitian ini diharapkan dapat dijadikan bahan masukan serta bahan pertimbangan bagi penyelenggara Diklat Berjenjang Tingkat Dasar di Wilayah Kota Cimahi baik yang 
dilaksanakan oleh pihak pemerintah maupun pihak swasta.

3. Sebagai bahan kajian dan kontribusi bagi Prodi Pendidikan Anak Usia Dini yang diharapkan dapat bermanfaat dalam rangka pengembangan disiplin pengetahuan

\section{B. KAJIAN TEORI DAN METODE}

Adapun teori yang melandasi dalam penelitian ini adalah: konsep Pendidikan dan Pelatihan, Konsep Kompetensi Profesional, Konsep Kompetensi Sosial, Konsep Diklat Berjenjang Tingkat Dasar.

\section{Konsep Pendidikan dan Pelatihan}

\section{a. Pengertian Pendidikan dan Pelatihan}

Dilihat dari istilah pendidikan dan pelatihan maka istilah tersebut terdiri dari dua kata yaitu kata pendidikan dan kata pelatihan. Kata pendidikan dan kata pelatihan dalam beberapa kepustakaan dijelaskan memiliki pengertian yang tidak sama atau dengan kata lain memiliki pengertian sendiri-sendiri. Demikian pula terdapat kepustakaan yang lainnya menyatakan bahwa pendidikan dan pelatihan merupakan satu istilah atau dengan kata lain memiliki pengertian yang satu.

Dalam Peraturan Pemerintah No 101 Tahun 2000 tentang pendidikan dan pelatihan jabatan pegawai negeri sipil malah justru dijadikan satu atau disatukan menjadi pendidikan dan pelatihan yang selanjutnya disebut diklat. Demikian pula kemudian diklat tersebut diberi pengertian sebagai proses penyelenggaraan belajar mengajar dalam rangka meningkatkan kemampuan pegawai negeri sipil. Kemudian ada juga pendapat yang menyatakan bahwa pendidikan bahwa pendidikan dan pelatihan adalah suatu program kesempatan belajar yang direncanakan untuk menghasilkan anggota staf demi untuk memperbaiki penampilan seseorang yang telah mendapatkan tugas menduduki suatu jabatan tertentu (Wahjosumijo, 1999). Pendidikan dan pelatihan harus menjadi suatu program yang berkelanjutan atau paling tidak merupakan suatu bagian dari kehidupan dan upaya dalam mencapai tujuan organisasi yang perlu dilakukan secara berulang. Dalam pendidikan dan pelatihan seharusnya juga dipergunakan metodologi dan sistem atau metode penyampaian yang baru yang bisa dilakukan dengan metode studi lapangan, diskusi, seminar konferensi, role playing, simulasi, studi kasus, dan sebagainya.

\section{b. Tujuan Pendidikan dan Pelatihan}

Jika suatu organisasi atau lembaga menyelenggarakan pendidikan dan pelatihan bagi para pegawainya, terlebih dahulu perlu dijelaskan tujuan apa yang ingin dicapai dari latihan tersebut. Dengan tujuan yang jelas \& nyata, arah yang ingin dicapai dari diklat tersebut akan lebih jelas. Tujuan diklat merupakan pedoman dalam penyusunan program, pelaksanaan, dan penilaiannya.

Tujuan yang ingin dicapai dari penyelenggaraan diklat, umumnya mempunyai hubungan yang erat dengan jenis pelatihan yang akan diselenggarakan. Tujuan yang ingin dicapai dari penyelenggaraan pelatihan prajabatan akan berbeda dengan tujuan yang ingin dicapai dari diklat tersebut.

Program pengembangan Sumber Daya Manusia (SDM) melalui diklat yang diselenggarakan dalam suatu organisasi atau lembaga pada prinsipnya adalah untuk meningkatkan dan mengembangkan pengetahuan, sikap dan keterampilan pegawai atau anggota organisasi sehingga lebih efektif dan efisien dalam mencapai sasaran-sasaran program ataupun tujuan organisasi.

\section{c. Manfaat Pendidikan dan Pelatihan}

Pada dasarnya, manfaat dari diklat bagi seseorang adalah agar seseorang lebih mudah dalam melaksanakan tugasnya, sehingga akan lebih positif dalam menyumbang tenaga dan pikirannya bagi suatu organisasi. Di samping hal tersebut dengan diklat yang dapat membantu para pegawai mengembangkan kemampuannya kearah yang lebih baik dan dapat melakukan pekerjaan dengan efisien.

Para pegawai harus mendapatkan diklat yang diselenggarakan dengan sistematis, jika mereka akan melaksanakan pekerjaan dengan baik. Tidak menjadi soal betapapun ketatnya mereka diseleksi dan betapapun banyaknya bakat yang mereka miliki dalam bekerja, dengan latihan yang diselenggarakan secara sistematis adalah perlu jika mereka menginginkan cara yang terbaik dalam melaksanakan suatu pekerjaan.

Menurut Atmodiwirio (2002) menyatakan bahwa pendidikan dan pelatihan tersebut sangat diperlukan oleh suatu organisasi, karena memiliki berbagai manfaat diantaranya adalah:

1) Bermanfaat untuk memenuhi kebutuhan organisasi, organisasi membutuhkan orang- 
orang yang mampu melaksanakan tugas yang telah ditetapkan sesuai dengan pengertian jabatan

2) Bermanfaat untuk memenuhi kebutuhan pribadi, kebutuhan pribadi merupakan bagian bagian yang tidak terpisahkan dari organisasi

3) Bermanfaat untuk memenuhi kebutuhan investasi sumber daya manusia, diklat tak ubahnya sebagai pendidikan formal membutuhkan pengadaan biaya yang tidak sedikit.

4) Bermanfaat bagi setiap pejabat atau jenjang kepangkatan.

\section{Konsep Kompetensi Profesional}

\section{a. Pengertian Kompetensi Profesional}

Professional, ada tiga istilah yang sering salah atau tertukar ketika didefinisikan, yaitu profesi, professional, dan profesionalitas.

Menurut Udin Syaefudin (2009) yang dikutip dalam buku Amirullah Syarbini (2015:31) profesi pada hakikatnya merupakan suatu pekerjaan tertentu yang menuntut persyaratan khusus dan istimewa sehingga meyakinkan dan memperoleh kepercayaan pihak yang memerlukan . Jadi professional adalah suatu jabatan atau pekerjaan yang menuntut keahlian dari para anggotanya. Artinya, pekerjaan itu tidakbisa dilakukan oleh sembarang orang yang tidak dilatih dan tidak disiapkan secara khusus untuk melakukan pekerjaan itu.

Selain kata profesi, adapula kata profesional yang menunjuk pada dua hal. Pertama orang yang menyandang suatu profesi. Kedua penampilan seseorang dalam melakukan pekerjaannya yang sesuai dengan profesinya.

Adapun kata profesionalitas berarti sikap para anggota profesi terhadap profesinya serta derajat pengetahuan dsn kejelian yang mereka miliki dalam rangka melakukan pekerjaannya (Ismail Kusmayadi, 2014:14) dalam buku Amirullah Syarbini (2015:32).

Menurut Amirullah Syarbini dalam bukunya yang berjudul guru hebat indonesia (2015:37) bahwasanya kompetensi professional merupakan penguasaan materi kurikulum secara luas dan mendalam, yang mencakup penguasaan materi kurikulum mata pelajaran di sekolah dan subtansi keilmuan yang menaungi materinya, serta penguasaan terhadap struktur dan metodologi keilmuan. Setiap subkompetensi tersebut memiliki indikator esensial sebagai berikut.
Subkompetensi menguasai subtansi keilmuan yang terkait dengan bidang studi memiliki indicator esensial; memahami materi ajar yang ada dalam kurikulum sekolah; memahami struktur, konsep, dan metode keilmuan yang menaungi atau koheren dengan materi ajar; memahami hubungan konsep antar mata pelajaran terkait, dan menerapkan konsep-konsep keilmuan dalam kehidupan sehari-hari.

Subkompetensi menguasai struktur dan metode keilmuan memiliki indicator; menguasai langkahlangkah penelitian dan kajian kritis untuk memperdalam pengetahuan atau materi bidang studi secara professional dalam konteks global.

Sebagai pendidik professional, guru bukan saja dituntut melaksanakan tugasnya secara professional, tetapi juga harus memiliki pengetahuan dan kemampuan professional. Dalam diskusi pengembangan model pendidikan professional tenaga kependidikan, yang diselenggarakan oleh PPS IKIP Bandung tahun 1990, dirumuskan 10 ciri profesi, yaitu:

1) Memiliki fungsi dan signifikansi sosial.

2) Memiliki keahlian / keterampilan tertentu.

3) Keahlian/keterampilan diperoleh dengan menggunakan teori dan metode ilmiah.

4) Didasarkan atas disiplin ilmu yang jelas.

5) Diperoleh dengan pendidikan dalam masa tertentu yang cukup lama.

6) Aplikasi dan sosialisasi nilai-nilai professional.

7) Memiliki kode etik.

8) Kebebasan untuk memberikan judgement dalam memecahkan masalah dalam lingkup kerjannya.

9) Memiliki tanggung jawab professional dan otonomi.

10) Ada pengakuan dari masyarakat dan imbalan atas layanan profesinya.

b. Indikator Kompetensi Profesional

Ada sepuluh kompetensi guru menurut Proyek Pembinaan Pendidikan Guru (P3G)

1) Menguasai bahan

2) Mengelola program belajar mengajar

3) Mengelola kelas

4) Menggunakan media atau sumber belajar

5) Menguasai landasan pendidikan

6) Mengelola interaksi belajar-mengajar

7) Menilai prestasi belajar-mengajar

8) Mengenal fungsi bimbingan dan penyuluhan

9) Mengenal dan meyelenggarakan admistrasi sekolah 
10) Memahami dan menafsirkan hasil penelitian guna keperluan pengajaran

Kompetensi professional adalah kemampuan menguasai materi pembelajaran secara luas dan mendalam. Sub kompetensi dalam kompetensi Profesional: Menguasai substansi keilmuan yang terkait dengan bidang studi yang meliputi memahami materi ajar yang ada dalam kurikulum sekolah, memahami struktur, konsep dan metode keilmuan yang menaungi atau koheren dengan materi ajar, memahami hubungan konsep antar mata pelajaran terkait, dan menerapkan konsepkonsep keilmuan dalam kehidupan sehari-hari. Dalam bidang kurikulum, guru harus mampu mengembangkan dan menjadikan sebagai pedoman proses belajar mengajar.

UU No. 14 Tahun 2005 ayat (1) menyatakan profesi guru dan profesi dosen merupakan bidang pekerjaan khusus yang dilaksanakan berdasarkan prinsip, bakat, minat, panggilan jiwa, dan idealisme, memiliki komitmen untuk meningkatkan mutu pendidikan, keimanan ketakwaan, dan akhlak mulia, memiliki kualifikasi akademik dan latar belakang pendidikan sesuai dengan bidang tugas, memilki kompetensi yang diperlukan sesuai dengan bidang tugas, memilki tanggung jawab atas pelaksanaan tugas keprofesionalan guru. Kemudian ayat (2), menyatakan pemberdayaan profesi guru atau pemberdayaan profesi dosen diselenggarakan melalui pengembangan diri yang dilakukan secara demokratis, berkeadilan, tidak diskriminatif, dan berkelanjutan dengan menjunjung tinggi hak asasi manusia, nilai keagamaan, nilai cultural, kemajemukan bangsa, dan kode etik profesi. Pelaksanaan undangundang tentang guru dan dosen ini memiliki misi yaitu mengangkat martabat guru, menjamin hak guru, meningkatkan kompetensi guru, memajukan profesi dan karir guru dan mutu pembelajaran, meningkatkan mutu pendidikan nasional, mengurangi kesenjangan ketersediaan guru antar daerah dari segi, kualifikasi akademik, dan mengurangi kesenjangan mutu pendidikan, dan meningkatkan pelayanan pendidikan yang bermutu.

\section{Konsep Kompetensi Sosial}

\section{a. Pengertian Kompetensi Sosial}

Menurut Buchari Alma (2008: 142), kompetensi sosial adalah kemampuan guru dalam berkomunikasi dan berinteraksi secara efektif dengan lingkungan sekolah maupun di luar lingkungan sekolah (Wibowo dan Hamrin, 2012: 124). Seorang guru harus berusaha mengembangkan komunikasi dengan orang tua peserta didik sehingga terjalin komunikasi dua arah yang berkelanjutan. Dengan adanya komunikasi dua arah, peserta didik dapat dipantau secara lebih baik dan dapat mengembangkan karakternya secara lebih efektif pula. Suharsimi juga memberikan argumennya mengenai kompetensi sosial. Menurut beliau, kompetensi sosial haruslah dimiliki seorang guru, yang mana guru harus memiliki kemampuan dalam berkomunikasi dengan siswa, sesama guru, kepala sekolah, dan masyarakat sekitarnya.

Dalam Standar Nasional Pendidikan, Pasal 28 ayat (3) butir d, dikemukakan bahwa yang dimaksud dengan kompetensi sosial adalah kemampuan guru sebagai bagian dari masyarakat untuk berkomunikasi dan bergaul secara efektif dengan peserta didik, sesama pendidik, tenaga kependidikan, orang tua/wali peserta didik, dan masyarakat sekitar (Mulyasa, 2007: 173). Hal tersebut diuraikan lebih lanjut dalam RPP tentang guru, bahwa kompetensi sosial merupakan kemampuan guru sebagai bagian dari masyarakat yang sekurang-kurangnya memiliki kompetensi untuk:

a) Berkomunikasi secara lisan, tulisan, dan isyarat.

b) Menggunakan tekhnologi komunikasi dan informasi secara fungsional.

c) Bergaul secara efektif dengan siswa, sesama pendidik, tenaga kependidikan, dan orang tua/wali peserta didik.

d) Bergaul secara santun dengan masyarakat sekitar (Mulyasa, 2007: 173).

\section{b. Indikator Kompetensi Sosial}

Kompetensi sosial menurut Slamet yang dikutip oleh Sagala dalam bukunya kemampuan Profesional Guru dan tenaga Kependidikan terdiri dari sub kompetensi yaitu :

1) Memahami dan menghargai perbedaan serta memiliki kemampuan untuk mengelola konflik dan benturan,

2) Melaksanakan kerja sama secara harmonis,

3) Membangun kerja team (team work) yang kompak, cerdas, dinamis dan lincah

4) Melaksanakan komunikasi secara efektif dan menyenangkan,

5) Memiliki kemampuan untuk memahami dan menginternalisasikan perubahan lingkungan yang berpengaruh terhadap tugasnya, 
6) Memiliki kemampuan menundukkan dirinya dalam system nilai yang berlaku di masyarakat,

7) 7. Melaksanakan prinsip tata kelola yang baik (Sagala, 2009: 38).

Berdasarkan beberapa pengertian kompetensi sosial di atas, dapat disimpulkan bahwa kompetensi sosial guru adalah kemampuan dan kecakapan seorang guru dalam berkomunikasi dan berinteraksi secara efektif pada pelaksanaan proses pembelajaran serta masyarakat sekitar. Kompetensi sosial adalah kemampuan seseorang berkomunikasi, bergaul, bekerja sama, dan memberi kepada orang lain. Kompetensi sosial ialah kemampuan seorang guru dan dosen untuk berkomunikasi dan berinteraksi secara efektif dan efisien dengan peserta didik, guru, orang tua, dan masyarakat sekitar

\section{Konsep Diklat Dasar}

Diklat Dasar adalah diklat yang dilaksanakan dengan beban sebanyak 48 pelajaran @ 45 menit ditujukan untuk mempersiapkan pendidik sebagai pengasuh dengan kompetensi minimal. Penyelenggara diklat ini adalah lembaga/institusi yang memiliki tugas dan fungsi meningkatkan mutu pendidik pada umumnya dan pendidik paud pada khususnya baik yang didukung oleh dana APBN, APBD maupun sumber dana lainnya. Bagi lembaga non pemerintah kriteria penyelenggaa diklat adalah:

a. Memiliki Akta Notaris/Badan Hukum

b. Memiliki izin operasional penyelenggaraan diklat dari pihak yang berwenang

c. Mempunyai sumber daya manusia yang handal dalam penyelenggaraan diklat berjenjang pendidik paud

d. Memiliki pengalaman dalam menyelenggarakan diklat tentang PAUD

e. Mampu menyediakan narasumber dan fasilitator yang kompeten di bidangnya

f. Mampu membuat dan mengembangkan program diklat yang mengacu pada pedoman dari pusat

Materi diklat Dasar adalah sebagai berikut:

Tabel 1

Materi Diklat Dasar

\begin{tabular}{|l|c|c|c|c|}
\hline \multirow{2}{*}{ No } & \multirow{2}{*}{ Materi } & \multicolumn{3}{|c|}{$\begin{array}{c}\text { Jam } \\
\text { Pelajaran }\end{array}$} \\
\cline { 3 - 5 } & & \multicolumn{3}{|c|}{ Teori } \\
\hline & Materi Umum & & & \\
\hline 1. & Kebijakan Dit P2TK & 2 & - & 2 \\
\hline
\end{tabular}

\begin{tabular}{|l|l|c|c|c|}
\hline & PAUDNI & & & \\
\hline 2. & $\begin{array}{l}\text { Kebijakan } \\
\text { Dit.PPAUD }\end{array}$ & 2 & - & 2 \\
\hline & \multicolumn{1}{|c|}{ Materi Pokok } & & & \\
\hline 3. & Konsep Dasar PAUD & 4 & - & 4 \\
\hline 4. & Perkembangan Anak & 2 & 2 & 2 \\
\hline 5. & $\begin{array}{l}\text { Pengenalan Anak } \\
\text { Berkebutuhan } \\
\text { Khusus }\end{array}$ & 2 & 2 & 4 \\
\hline 6. & $\begin{array}{l}\text { Cara Belajar Anak } \\
\text { Usia Dini (Bermain } \\
\text { dan Anak) }\end{array}$ & 4 & 4 & 8 \\
\hline 7. & $\begin{array}{l}\text { Kesehatan dan Gizi } \\
\text { Anak Usia Dini }\end{array}$ & 2 & 3 & 5 \\
\hline 8. & $\begin{array}{l}\text { Etika dan Karakter } \\
\text { Pendidik PAUD }\end{array}$ & 4 & - & 4 \\
\hline 9. & $\begin{array}{l}\text { Perencanaan } \\
\text { Pembelajaran }\end{array}$ & 2 & 4 & 6 \\
\hline 10. & $\begin{array}{l}\text { Evaluasi } \\
\text { Pembelajaran }\end{array}$ & 2 & 3 & 5 \\
\hline 11. & $\begin{array}{l}\text { Komunikasi dalam } \\
\text { Pengasuhan }\end{array}$ & 2 & 2 & 4 \\
\hline
\end{tabular}

Adapun kriteria khusus peserta diklat dasar tampak pada tabel di bawah ini.

Tabel 2

Kriteria Khusus Diklat Dasar

\begin{tabular}{|c|l|l|}
\hline No & \multicolumn{1}{|c|}{ Aspek } & \multicolumn{1}{c|}{ Diklat Dasar } \\
\hline 1 & Usia & Minimal 17 Tahun \\
\hline 2 & Pendidikan & SMA atau Sederajat \\
\hline 3 & Pengalaman Kerja & $\begin{array}{l}\text { 1 Tahun ditunjukan } \\
\text { dengan SK Masih aktif }\end{array}$ \\
\hline 4 & $\begin{array}{l}\text { Pengalaman } \\
\text { Mengikuti } \\
\text { Pelatihan }\end{array}$ & $\begin{array}{l}\text { Diutamakan pernah } \\
\text { Mengikuti pelatihan } \\
\text { PAUD }\end{array}$ \\
\hline
\end{tabular}

\section{Metodologi}

Metode yang digunakan dalam penelitian ini adalah metode deskriptif. Metode deskriptif dianggap sebagai metode yang paling relevan untuk digunakan dalam penelitian. Karena penelitian ditujukan pada masalah yang terjadi pada masa sekarang dan dalam pelaksanaannya tidak terbatas pada pengumpulan data dan penyusunan data, akan tetapi lebih jauh lagi dianalisis setiap data yang terkumpul. Adapun penelitiannya adalah korelasional yang bertujuan untuk mengetahui: "Efektivitas Diklat Berjenjang Tingkat Dasar terhadap kompetensi profesional dan Kompetensi Sosial pendidik PAUD.

Selain menggunakan metode deskriptif, penelitian ini juga menggunakan dua metode 
statistik untuk menganalisa data yaitu statistik deskriptif untuk mengukur nilai rata-rata simpangan baku serta statistik inferensial yaitu dalam bentuk analisis regresi dan analisis korelasi. Analisis regresi digunakan untuk mengungkapkan hubungan fungsional antara variabel-variabel penelitian, sedangkan analisis korelasi digunakan untuk mengukur derajat keeratan atau hubungan variabel penelitian.

\section{HASIL PENELITIAN DAN PEMBAHASAN}

1. Menganalisis Kompetensi Profesional Pendidik PAUD setelah Mengikuti Diklat Berjenjang Tingkat Dasar di Kota Cimahi Dari hasil pengolahan data mengenai variabel kompetensi pedagogik pendidik PAUD menunjukan pada kategori yang sangat tinggi. Hal ini dilihat dari rata-rata skor umum responden sebesar 87,92, apabila skor ini dibandingkan dengan skor ideal diperoleh skor kecenderungan responden sebesar 83,73\%.

Penguasaan kompetensi profesional erat kaitannya dengan kemampuan seorang guru. Profesionalisme merupakan syarat untuk mencapai prestasi. Menurut para ahli, profesionalisme menekankan kepada penguasaan ilmu pengetahuan atau kemampuan manajemen beserta strategi penerapannya. Profesionalisme guru bukan sekadar pengetahuan teknologi dan manajemen tetapi lebih merupakan sikap, pengembangan profesionalisme lebih dari seorang teknisi bukan hanya memiliki keterampilan yang tinggi tetapi memiliki suatu tingkah laku yang dipersyaratkan

\section{Menganalisis kompetensi sosial pendidik PAUD setelah mengikuti Diklat Berjenjang Tingkat Dasar di Kota Cimahi}

Dari hasil pengolahan data mengenai variabel kompetensi sosial pendidik PAUD menunjukan pada kategori yang sangat tinggi. Hal ini dilihat dari rata-rata skor umum responden sebesar 70,90, apabila skor ini dibandingkan dengan skor ideal diperoleh skor kecenderungan responden sebesar $88,62 \%$.

Sebagai professional yang memiliki tugas memajukan para siswa sehingga mereka bisa masuk dunia profesi dan diterima dalam semua kalangan sosial, seorang guru harus memiliki kompetensi sosial untuk tiga konteks kepentingan, yakni:
Pertama, mempersiapkan para siswa untuk memasuki dunia profesi, baik sebagai pegawai, pegawai negeri sipil, polisi, tentara, pegawai swasta, pengusaha, atau bahkan pemimpin politik yang kekuatannya terletak pada konstituen dan kesuksesannya berada kemampuan komunikasi sosialnya. Oleh sebab itu, para siswa harus dilatih untuk bisa memiliki kompetensi sosial, memiliki kecakapan untuk berkomunikasi, mempengaruhi orang lain, meyakinkan orang lain untuk bisa melakukan sesuatu sesuai dengan apa yang dia yakni, termasuk kemampuan menerima keragaman sosial, etnik, agama, ras dan budaya. Semua itu harus dilatih sejak mereka berada di sekolah

Kedua, memperkuat profesionalisme melalui proses peer-guidence, peer review sesama guru, baik di internal maupun lintas satuan pendidikan. Guru yang cenderung introvet, tertutup, dan tidak banyak berkomunikasi dengan sesama di sekolahnya, akan teralienasi dan tertinggal oleh berbagai perubahan. Sementara dalam lintas satuan pendidikan, pemerintah mendorong para guru memiliki wadah komunikasi satu sama lain. Dalam hal ini, pemerintah membantuk wadah guru PAUD dengan IGTKI, HIMPAUDI, IGRA, dll. Organisasi ini dibentuk dan dikembangkan bagi para guru untuk melakukan sharing tentang bahan ajar, metode dan strategi pembelajaran, evaluasi proses dan hasil belajar, pengelolaan kelas serta pengembangan penelitian untuk peningkatan layanan pembelajaran bagi para siswa mereka.

Ketiga, memperkuat institusi pendidikan melalui optimalisasi partisipasi seluruh stakeholder sekolah guna meningkatkan mutu layanan pendidikan. Demikian pula saat para guru mencari informasi tentang kebutuhan-kebutuhan para pengguna lulusan, mereka harus mampu berkomunikasi dengan para pengguna, mendengarkan secara serius dan seksama, termasuk menghargai pendapat-pendapat mereka. Semua hal ini harus dilakukan setiap guru sekaligus merupakan kewajiban yang mengikat mereka, karena akan selalu ada setiap tahun dan harus dilakukan sebagai tugas rutin.

Untuk lebih mengembangkan kompetensi sosial guru PAUD yang harus dilakukan dalam mengembangkan proses pembelajaran yang sekaligus melatih kompetensi sosial siswa melalui langkah-langkah sebagai berikut: 
a. Memberi kesempatan kepada para siswa untuk bertanya kepada sesama temannya, dan juga kepada guru, agar mereka memiliki kecakapan bagaimana berkomunikasi dengan orang lain.

b. Mengembangkan diskusi kelas pada topiktopik yang sesuai dengan perkembangan usia mereka.

c. Memberikan cerita-cerita pendek dan lucu tentang baik dan buruk yang dapat mereka ceritakan kembali pada teman-temannya.

\section{Menganalisis Efektivitas Diklat Berjenjang Tingkat Dasar terhadap peningkatan kompetensi profesional dan sosial Pendidik Anak Usia Dini di Kota Cimahi}

Penelitian yang dilakukan mengajukan satu hipotesis, hasil analisis ini membuktikan hipotesa penelitian yang menyatakan bahwa: "Terdapatnya hubungan yang berarti antara Efektivitas Diklat Berjenjang Tingkat Dasar terhadap Kompetensi Profesional Pendidik PAUD di Kota Cimahi”. Dari pengujian yang dilakukan hipotesis yang telah diajukan dalam penelitian ini diterima, hipotesis yang menguji kedua variabel $\mathrm{X}$ dan Variabel $\mathrm{Y}$ dibuktikan dengan mengujikan $t$ hitung yang memperoleh nilai lebih besar dari $t$ tabel pada tingkat kepercayaan $95 \%$ dengan $\mathrm{dk}=106$.

Hasil analisis data penelitian mengenai efektivitas diklat berjenjang tingkat dasar terhadap peningkatan kompetensi profesional pendidik PAUD di Kota Cimahi, berdasarkan perhitungan menunjukan bahwa persamaan regresi yang diperoleh adalah $\mathrm{Y}=46,106+0.665$ $\mathrm{X}$ koefisien regresi yang diperoleh menunjukan harga yang positif. Makin tinggi efektivitas diklat berjenjang tingkat dasar, maka makin tinggi pula atau semakin baik pula kompetensi profesional pendidik PAUD di Kota Cimahi. Perubahan pada kompetensi pendidik PAUD di Kota Cimahi terjadi 0,665 satuan setiap penambahan penggunaan Diklat berjenjang tingkat dasar sebesar satu satuan dengan persentase setiap peningkatan penggunaan Diklat Berjenjang Tingkat Dasar yang dilaksanakan di Kota Cimahi sebesar $100 \%$, maka kompetensi profesional pendidik PAUD akan meningkat sebesar $66,5 \%$. Berarti efektivitas pelaksanaan diklat berjenjang tingkat dasar dapat meningkatkan kompetensi profesional pendidik PAUD. Oleh karena itu semakin tinggi efektivitas penggunaan Diklat berjenjang tingkat dasar yang dilaksanakan di HIMPAUDI Kota Cimahi maka semakin tinggi pula kompetensi profesional pendidik PAUD di Kota Cimahi. Dengan demikian, untuk menaikan tingkat kompetensi pendidik PAUD perlu lebih ditingkatkan mengenai efektivitas pelaksanaan diklat berjenjang tingkat dasar.

Pada perhitungan koefisien determinasi menunjukan bahwa efektivitas diklat berjenjang tingkat dasar dalam meningkatkan kompetensi profesional pendidik PAUD di Kota Cimahi adalah 23,9 \% sedangkan sisanya $76,1 \%$ dipengarui oleh faktor lain. Berdasarkan kontribusi tersebut diatas, penggunaan diklat berjenjang tingkat dasar bukan satu-satunya faktor yang mempengaruhi kompetensi profesional pendidik PAUD, namun penggunaan diklat berjenjang tingkat dasar perlu ditingkatkan dalam meningkatkan kompetensi profesional pendidik PAUD di Kota Cimahi.

Penelitian yang dilakukan dengan mengajukan hipotesis kedua, hasil analisis ini membuktikan hipotesa penelitian yang menyatakan bahwa: "Terdapatnya hubungan yang berarti antara Efektivitas Diklat Berjenjang Tingkat Dasar terhadap Kompetensi Sosial Pendidik PAUD di Kota Cimahi”. Dari pengujian yang dilakukan hipotesis yang telah diajukan dalam penelitian ini diterima, hipotesis yang menguji kedua variabel $X$ dan Variabel $Y$ dibuktikan dengan mengujikan $\mathrm{t}$ hitung yang memperoleh nilai lebih besar dari $\mathrm{t}$ tabel pada tingkat kepercayaan $95 \%$ dengan $\mathrm{dk}=$ 106.

Hasil analisis data penelitian mengenai efektivitas diklat berjenjang tingkat dasar terhadap peningkatan kompetensi sosial pendidik PAUD di Kota Cimahi, berdasarkan perhitungan menunjukan bahwa persamaan regresi yang diperoleh adalah $\mathrm{Y}=40,846+0.886 \mathrm{X}$ koefisien regresi yang diperoleh menunjukan harga yang positif. Makin tinggi efektivitas diklat berjenjang tingkat dasar, maka makin tinggi pula atau semakin baik pula kompetensi sosial pendidik PAUD di Kota Cimahi. Perubahan pada kompetensi pendidik PAUD di Kota Cimahi terjadi 0,886 satuan setiap penambahan penggunaan Diklat berjenjang tingkat dasar sebesar satu satuan dengan persentase setiap peningkatan penggunaan Diklat Berjenjang Tingkat Dasar yang dilaksanakan di Kota Cimahi sebesar $100 \%$, maka kompetensi sosial pendidik PAUD akan meningkat sebesar 88,6\%. Berarti efektivitas pelaksanaan diklat berjenjang 
tingkat dasar dapat meningkatkan kompetensi sosial pendidik PAUD. Oleh karena itu semakin tinggi efektivitas penggunaan Diklat berjenjang tingkat dasar yang dilaksanakan di HIMPAUDI Kota Cimahi maka semakin tinggi pula kompetensi sosial pendidik PAUD di Kota Cimahi. Dengan demikian, untuk menaikan tingkat kompetensi pendidik PAUD perlu lebih ditingkatkan mengenai efektivitas pelaksanaan diklat berjenjang tingkat dasar.

Pada perhitungan koefisien determinasi menunjukan bahwa efektivitas diklat berjenjang tingkat dasar dalam meningkatkan kompetensi sosial pendidik PAUD di Kota Cimahi adalah $31,1 \%$ sedangkan sisanya $68,9 \%$ dipengarui oleh faktor lain. Berdasarkan kontribusi tersebut diatas, penggunaan diklat berjenjang tingkat dasar bukan satu-satunya faktor yang mempengaruhi kompetensi sosial pendidik PAUD, namun penggunaan diklat berjenjang tingkat dasar masih perlu ditingkatkan.

\section{SIMPULAN}

Berdasarkan hasil analisis data yang telah diuraikan pada bab terdahulu secara keseluruhan dapat dikemukakan kesimpulan sebagai berikut: Menganalisis kompetensi profesional pendidik PAUD setelah mengikuti Diklat Berjenjang Tingkat Dasar di Kota Cimahi.

Dari hasil pengolahan data mengenai variabel kompetensi pedagogik pendidik PAUD menunjukan pada kategori yang sangat tinggi. Hal ini dilihat dari rata-rata skor umum responden sebesar 87,92, apabila skor ini dibandingkan dengan skor ideal diperoleh skor kecenderungan responden sebesar 83,73\%. Sedangkan dari hasil pengolahan data mengenai variabel kompetensi sosial pendidik PAUD menunjukan pada kategori yang sangat tinggi. Hal ini dilihat dari rata-rata skor umum responden sebesar 70,90, apabila skor ini dibandingkan dengan skor ideal diperoleh skor kecenderungan responden sebesar 88,62\%.

Hasil analisis data penelitian mengenai efektivitas diklat berjenjang tingkat dasar terhadap peningkatan kompetensi sosial pendidik PAUD di Kota Cimahi, berdasarkan perhitungan menunjukan bahwa persamaan regresi yang diperoleh adalah $\mathrm{Y}=40,846+0.886 \mathrm{X}$ koefisien regresi yang diperoleh menunjukan harga yang positif. Makin tinggi efektivitas diklat berjenjang tingkat dasar, maka makin tinggi pula atau semakin baik pula kompetensi sosial pendidik PAUD di Kota Cimahi.

Perubahan pada kompetensi pendidik PAUD di Kota Cimahi terjadi 0,886 satuan setiap penambahan penggunaan Diklat berjenjang tingkat dasar sebesar satu satuan dengan persentase setiap peningkatan penggunaan Diklat Berjenjang Tingkat Dasar yang dilaksanakan di Kota Cimahi sebesar $100 \%$, maka kompetensi sosial pendidik PAUD akan meningkat sebesar $88,6 \%$. Berarti efektivitas pelaksanaan diklat berjenjang tingkat dasar dapat meningkatkan kompetensi sosial pendidik PAUD. Oleh karena itu semakin tinggi efektivitas penggunaan Diklat berjenjang tingkat dasar yang dilaksanakan di HIMPAUDI Kota Cimahi maka semakin tinggi pula kompetensi sosial pendidik PAUD di Kota Cimahi. Dengan demikian, untuk menaikan tingkat kompetensi pendidik PAUD perlu lebih ditingkatkan mengenai efektivitas pelaksanaan diklat berjenjang tingkat dasar.

\section{DAFTAR PUSTAKA}

Atmodiwirio. (2002). Manajemen Pelatihan. Jakarta: PT Pustaka

Buchari Alma. (2008). Manajemen Pemasaran dan Pemasaran Jasa. Bandung: Alfabeta

Direktorat Profesi Pendidik Dirjen Peningkatan Mutu Pendidik dan Tenaga Kependidikan (2006). Jakarta: Dirjen Tendik

Mulyasa, E. (2007). Menjadi Guru Profesional Menciptakan Pembelajaran Kreatif dan Menyenangkan. Bandung: Rosdakarya.

Peraturan Pemerintah N0 101 Tahun 2000 tentang Penddikan Dan Pelatihan Jabatan Pegawai Negeri Sipil.

Permendiknas Nomor 16 Tahun 2007 tentang Kualifikasi Akademik dan Kompetensi Guru. Standar kompetensi guru

Syaiful Sagala. (2009). Konsep dan Makna Pembelajaran. Bandung : CV. Alfabeta

Syarbini, Amirullah. (2016). Pendidikan Kharakter Berbasis Keluarga (Studi tentang Model Pendidikan Kharakter dalam Perspektif Islam). Yogyakarta: ArRuzz MediaUser, Usman. Menjadi Guru Professional. (Bandung: PT Remaja Rosdakarya,1998).

UU No 14 Tahun 2005 Tentang Guru dan Dosen. 
Wahjosumijo. (1999). Kepemimpinan Kepala Sekolah. Jakarta: Gramedia.

Wibowo, Agus dan Hamrin. (2012). Menjadi Guru Berkarakter. Yogyakarta: Pustaka Pelajar 